\title{
Sacred rituals and popular religiousness amongst transhumant shepherds of Teruel region, Spain
}

\author{
Pablo Vidal-González
}

\begin{abstract}
Seasonal migration of livestock, ascending and descending movements of livestock to escape from the rigours of winter, meant that shepherds from the region of Teruel in Spain used to spend more than six months away from their homes. This article analyses the profound popular cultures which have been passed down from generation to generation amongst these shepherds, a true cultural group, as well as the cosmovision and popular religiousness specific to this group, which have disappeared. We also analyse the strategies used in order to face danger and risks in a liminal job, on the limits of the unknown.
\end{abstract}

Keywords: Seasonal migration; Popular religiousness; Liminality; Shepherds; Mediterranean

\section{Background}

Seasonal migratory herding is characteristic of Mediterranean countries. Sheep and cattle are driven to higher summer pastures and descend to coastal areas in winter to escape from the cold. This activity became well known after Klein (1920) published his work on the subject, highlighting the importance of the Mesta institution in the management of seasonal migration in the Realm of the Crown of Castile. Similarly, the work of Violant i Simorra (1949) brought to light the wealth of both Aragonese and Catalan migratory herding in the Pyrenees mountains.

However, one of the lesser known areas of seasonal migration in the Iberian Peninsula, and yet of great importance, was located in the southern part of Aragon, with its mainly winter migrations from many parts of the province of Teruel towards the Valencian provinces, which was popularly known as bajar al Reino, and is representative of the importance of this typically Mediterranean migration.

This extensive phenomenon, which takes us back to at least the Christian conquest of the Realm of Valencia in 1238, mobilised for generations a large number of men not only from the Gudar-Javalambre mountainous regions but also from the rest of the other villages of the southern part of the province, especially the Albarracin mountain range.

Correspondence: pablo.vidal@ucv.es

Anthropology Research Institute, Universidad Católica de Valencia, Guillem de Castro, 94, Valencia 46003, Spain

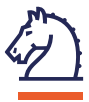

\section{Methodology}

This article presents the results of fieldwork conducted with shepherds and livestock owners, and with the inhabitants of the towns where the latter would spend the six-month winter period (Figures 1 and 2). Most of the interviews conducted over the three-year period of this study involved key figures who had at some time directly engaged in transhumance activities. Interviewees were elderly retired shepherds, many of whom have since died. Interviews took place in the shepherds' mountain hometowns and also in their winter habitats. In most cases, the interviews began with pasture managers from the host towns who put us in contact with former shepherds from Teruel. Thus, key interviews were conducted with people who were especially relevant, due to their having participated directly in pastoralist activities. 


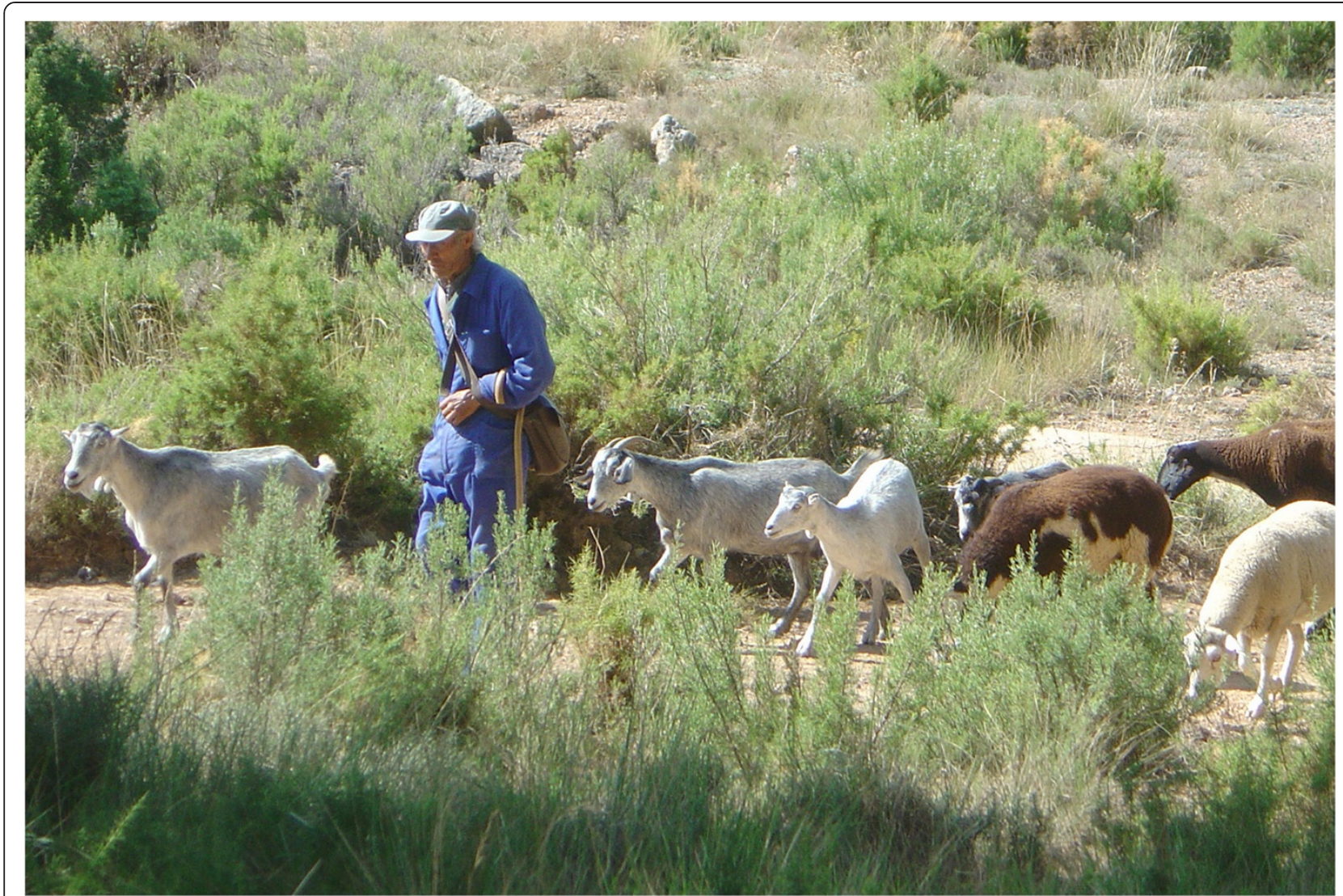

Figure 1 Shepherd and flock in the mountain pastures.

Interviews (Table 1) were conducted in the towns of Aín, Alcudia de Veo, Algimia de Almonacid, Almedijar, Ayodar, Eslida, Gaibiel, Higueras, Suera and Vall d'Almonacid, all of which are located in the Sierra de Espadán mountain range in Castellón. Further interviews took place in the shepherds' home towns in the mountains of Teruel, namely, Alcalá de la Selva, Fortanete, Gúdar, Pina de Montalgrao, Puebla de Valverde, Puertomingalvo, Riodeva and Valdelinares.

Interviews were semi-structured and based on a previously prepared script. The aim was to obtain as much information as possible on the transhumant shepherding practice, which represented an important economic activity until the end of the 1960s, after which time it fell into drastic decline. The importance of these interviews lies in the fact that the interviewees are the last witnesses to a multi-secular activity that has basically disappeared. In this paper, we will analyse the cosmovision of these roaming farmers, who did not belong anywhere as such but always moved along boundaries, in forbidden territories, in remote, wooded or wild areas and out of reach of the rest of the inhabitants of the villages. 'Shepherds cross endless frontiers and it is this that makes them prudent and strategic' (Agulló 2009, p. 82). They were liminal, marginal beings who were clearly situated on the fringes of rural areas.

At the same time, shepherds passed down through the generations a culture which was unique and inherited an ethical code of behaviour, of rituals, as well as a language which was different to the rest of the population. Castán (1999, p. 12) refers to this when he indicates that 'wherever they go it is obvious they belong to a society which is distinct, open and permeable but different: a society of shepherds'.

This wisdom and this knowledge was passed down from fathers to sons and firmly rooted in the age-old ways of managing and governing cattle and sheep. No female relatives or the rest of the neighbours were involved in this activity.

\section{Herders}

Migratory herders carried out their work not only far away from home, the family, spaces which were normally attributed to the world of women, but also far from the fields and farms that were to be found in the rural environment and which belonged to the world of men. They spent their lives in a world which was remote, strange and nomadic, and which was also marginal and suspicious. 


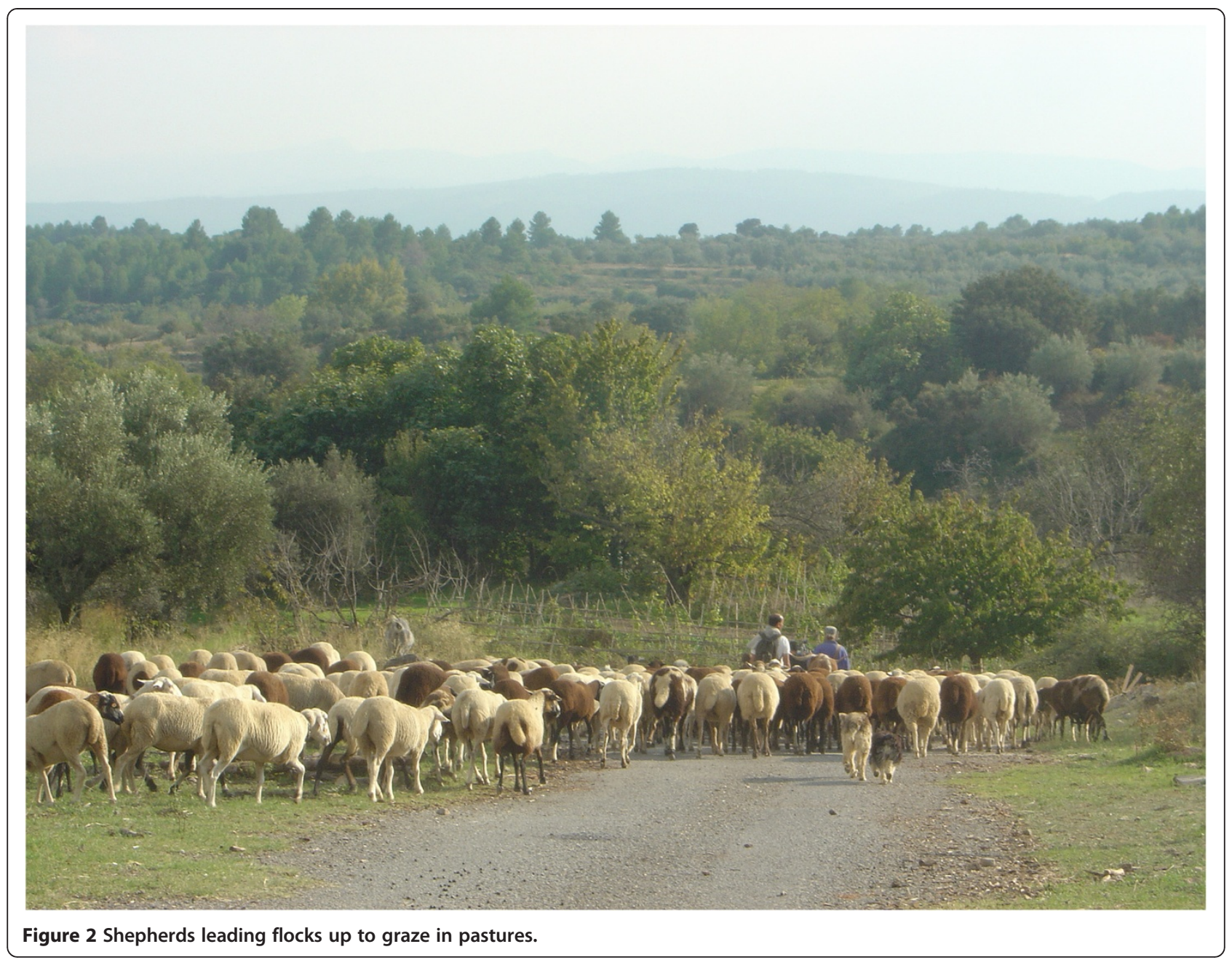

Serafín, from Vall d'Almonacid (see Table 1), offers us the following verse:

She has told me she does not love me because I am a shepherd and I save,Some day I will own the tiles of her roof.

A shepherd's world was a vague territory which could not be easily defined. But, above all, it was a space beyond what was known and controlled. Shepherds did not focus their world, their meeting points on the village square, the local bar or the local 'casino', or the church itself.

Shepherds did not sleep at home, did not eat with other people, did not share social events nor those moments when the community bonded and built a sense of belonging. Shepherds just did not belong. This is how Joaquín Pablo from Higueruelas relates it:

Shepherds are very gross and animal-like. During the day they walk the mountains and at night the stables.
Another local proverb also narrated by Serafín states that 'The shepherd's wife should sew stockings and save' and indicates that a shepherd's life took place far from home, distanced from household chores which would be carried out exclusively by his wife.

In the popular cosmovision, the shepherd was someone who was known to all but who lived in a parallel world distanced from everyone. This made him special. The aura of mystery, which had always surrounded shepherds, was heightened by their solitude, and therefore, they were automatically considered gruff and anti-social.

Moreover, they were in constant contact with bandits, passers-by and outlaws, with those who wished to evade social control and live in inhospitable caves and ravines. There existed a thin divide between shepherd and bandit which has never been clearly defined.

The unique personality of the shepherd intensified the idea of 'alterity' amongst the community, of a natural feeling of strangeness towards 'the other one', towards someone who, due to his occupation, was different to the rest of the members of the society. In a certain way, 
Table 1 Informant data

\begin{tabular}{llll}
\hline Name & Age & Village and province & Former occupation \\
\hline Manuel & 76 & La Vall d'Almonacid (Castellón) & Farmer \\
Sixto & 78 & Valdelinares (Teruel) & Shepherd \\
Serafín & 76 & La Vall d'Almonacid (Castellón) & Agriculture local council president \\
Silvino & 78 & La Vall d'Almonacid (Castellón) & Rural guard \\
Joaquín & 87 & Algimia d'Almonacid (Castellón) & Rural guard \\
Emilio & 78 & Aín (Castellón) & Rural guard \\
Luis & 73 & La Pobla de Valverde (Teruel) & Shepherd \\
Pascual & 72 & Suera (Castellón) & Agriculture local council president \\
José and Encarna & 69 & Eslida (Castellón) & Food shop owners \\
Ricardo & Fuentes de Ayodar (Castellón) & Agriculture local council president \\
Lionel & 72 & Fortanete (Teruel) & Shepherd and livestock owner \\
Joaquín Pablo & Higueruelas (Castellón) & Agriculture local council president \\
Vicente & 79 & Ayodar (Castellón) & Shepherd's son \\
Encarnación & 74 & Ayodar (Castellón) & Shepherd's daughter \\
Vicente & 83 & Pina de Montalgrao (Castellón) & Livestock owner \\
Manuel & 100 & Puebla de Valverde (Castellón) & Livestock owner \\
David & 81 & Alcudia de Veo (Castellón) & Agriculture local council secretary \\
Delfina & 72 & Pina de Montalgrao (Castellón) & Livestock owner \\
Manuel & 76 & Riodeva (Teruel) & Shepherd \\
\hline
\end{tabular}

the shepherd was like a sailor, nomadic, without a fixed date of return, sailing in unknown waters, without any protection from the vicissitudes of nature, and without fixed abode, with a 'woman in each port', not because this was actually true, but because he was beyond the control of the rest of the community. It is commonly heard that shepherds are not men but rather something else and exist on a different level. Vicente, a livestock owner from Pina de Montalgrao, relates a conversation that he remembered very well, between a child and his mother which he overheard many years before in Valencian lands one winter: 'Mother, there is a man over there!' 'No daughter, no, it is a shepherd'.

Ricardo, from Fuentes de Ayodar, sees things in a completely different light:

The shepherds in those upper lands make their owners rich, they cut the hair from their bums and make ropes and threads.

However, this alterity did not necessarily imply alienation since it did have its important privileges.

A shepherd was exempt from obligatory military service, could not be arrested for debts held by his master, was excused for not fulfilling his paschal duties and did not usually pay his taxes as he had no fixed address and could not be found by the Treasury. Vicente, a flock owner from Pina de Montalgrao told as that 'shepherds were not given money but rather savings, which were exempt from all payments'.

Klein (1920, p. 56) had already referred to the number of privileges that shepherds had in modern times. 'The life of the shepherds was by no means one of privation and hardship. They and their families (...) were assured of special royal protection against town bailiffs'. At the same time, shepherds were fortunate people, since even though they had a hard job, which was just as hard as many other jobs, they had a job which was lucrative, first of all because of the wool and more recently, the meat. So, they used to enjoy a more comfortable life than the rest of their neighbours. David, the last secretary of the Brotherhood of Farmers of Alcudia de Veo, a village in the Espadán mountain range which received herders from the region of Teruel stated: 'shepherds were the only ones who had money'.

In times of hardship, shepherds were privileged since they had meat, something which their fellow villagers did not have. Shepherds descended from the mountains not only loaded with meat in order to survive the winter, and with new provisions every fortnight, but also when one of their sheep died due to illness or accident, something which was quite common in large flocks; there would be a spontaneous celebration in which the shepherds would participate with those whom they had the most affinity. These occasions were always remembered as being exceptional, as an extraordinary event. Emilio, a rural guard ${ }^{\mathrm{a}}$ from Aín, remembered that very well: 'When 
a sheep died, or was killed, the shepherds organised a feast'.

Joaquín, a rural guard from Algimia d'Almonacid, also mentioned this situation: 'On one occasion they gave two kilos of lamb as a present from a sheep that they had killed'.

Also at the end of winter, around about March, the sheep's tails were cut so that they did not bother them in summer and could avoid infections. In the old days, the tails were carefully scraped and cleaned and then were used for another feast. Curiously, this delicacy came from the meat of an animal which was still alive.

Shepherds used to give a sheep as a present, before returning to their mountain villages, so that the inhabitants of the valleys with whom they had lived could celebrate their 'fiestas'. Manuel, a farmer from Vall d'Almonacid, said to us 'they would give us a sheep at Christmas, and another one at Easter'. This custom can also be seen in Aín, Alcudia de Veo and Gaibiel.

\section{Shepherds and the sacred in the rural environment}

A shepherd's workshop was the mountain: an inhospitable and remote territory, uncolonised, and therefore strange and full of risks. The mountains were an unknown, dangerous and mystical place. A shepherd was a special being, capable of coping in this environment, of 'domesticating' it and making sense of it. He had to be able to use all his skills to carry out his work in this context, and to do this, he needed the help of a Supreme Being: God.

A relationship was therefore started, well-documented since ancient times, which was full of complicity. It would be true to say that, in the eyes of his neighbours, there was no one closer to God than a shepherd and, more so, a transhumant shepherd who worked and lived in the middle of an indomitable environment created by God.

It is not necessary to bring to mind here the innumerable appearances, meetings and miracles of which shepherds were protagonists and the transmitters of the Divine Will to the rest of mortals. This tradition was not only due to a close relationship and assiduous encounters with the Divine but due also to the privilege of a shepherd's aura of innocence after being the first to recognise and worship Baby Jesus.

Delfina, one of our sources in Pina de Montalgrao, a village of Castellón which borders with Teruel and is steeped in migratory herding history, said: 'a shepherd suffered great hardship, but had relief in being the first to worship Baby Jesus'.

This ancient privilege was kept alive by word of mouth as Vicente, a shepherd's son from Ayodar, also to be found in the Espadán mountain range, recalls:
Shepherds are not shepherds, but angels from the sky, who are brought up in the mountains, just like Baby Jesus.

Shepherds celebrated Christmas with special merriment, singing and dancing jotas ${ }^{\mathrm{b}}$ around a bonfire at the steps of the church, according to a source in Suera, a village of winter pastures in the Espadán mountain range in the province of Castellón.

However, shepherds were considered suspicious beings, not only within their own communities, since they did not attend acts of devotion as did the rest of their neighbours, but also by the rest of the people whom they encountered. Shepherds seldom took part in public events where the local community gathers: baptisms, communions, weddings and burials, nor in local festivities or the priest's sermons at Sunday Mass. They were not sociable people, basically because their obligations made it impossible for them to share their almost nonexistent leisure time with their neighbours.

This is well remembered by Luís, a shepherd from Puebla de Valverde. He took out his flock in the morning, before going to the church, to get married at midday. The following day, he continued with his obligations without any concession to his free time, his honeymoon or even a brief period of rest in his home.

Their faith was peculiar. It was not conveyed via their mothers with whom they lost contact at the age of 12 but rather via their fathers and not through the habitual catechism pathways. What is more, their faith was generated in fields, in the mountains, in lands which were not cultivated, and not 'domesticated'. This created a strong religious feeling which was sacred and a feeling of direct divine protection. But there was also heterodoxy, religious autonomy and self-taught religion, different from the rest of the society.

The feeling of evident proximity to God was due to the acknowledgement that shepherds could not ask for protection from anyone else against the numerous dangers and calamities that the mountains hold, both natural and provoked by men: those dangers caused by severe weather conditions (droughts, frosts, blizzards, hailstorms, fog), those caused by vermin and wild animals (wolves, foxes, wild dogs, bears) and also those related to the greed of those who coveted the shepherd's possessions. Only He would be able to save the shepherd, and this belief would motivate shepherds to develop many supernatural strategies in order to seek help.

In the first place, a transhumant shepherd was the bearer of a deep, cultural tradition of shepherding which was passed down from father to son. The tradition of shepherding had extraordinary similarities in different geographical regions which had no apparent connection between them. There was a strong common substratum. 
However, the major economic transformations which happened during the second half of the twentieth century, together with the exodus from rural areas, the depopulation of small villages and the loss of traditional trades, has made it difficult to trace these cultural traditions.

This wealth of cultural tradition had been maintained with much difficulty, in a large group of shepherds, most of them retired. These shepherds from the Teruel mountainous areas of Gúdar and Javalambre made their way down to the Valencian regions in order to escape from the severe winter cold (Vidal-González and Antón 2006).

\section{Magical resources of protection}

As noted, the workshop of a shepherd was precisely that area which had not been touched by his fellow neighbours or by those who inhabited the villages which he passed through or spent his winters. In fact, a shepherd had a special interest in avoiding inhabited areas and busy roads or paths since his approaching populated areas or grazing in sown fields could only cause chastisement. The solitude and isolation both offered several important symbolic components. The shepherd lived surrounded by vermin, in an uncivilised world which was strange and dangerous. His mission, as referred to by Turner (1974), was to be intrusive, and due to his liminality, he was considered by everyone to be in exile, a stranger, until he was accepted by his new neighbours; those with whom he spent half the year.

This is how Pascual, the Agriculture Local Council President from Suera, remembers it: 'Shepherds are always frowned upon'.

In fact, in the past, as a strategy of acceptance and as a rite of passage, it was quite frequent that a shepherd married a young woman from the lowlands. In this way, he not only received recognition in both lands but also legitimacy before his new neighbours and was frequently accepted as one more by the new group. Joaquín Pablo, Agriculture Local Council President from Higueruelas, refers us to a saying which reflects this vision: 'If I were to have three mules and barley to feed them, land to cultivate it on, then no doubt your parents would adore me'.

Amongst the different rituals which we have been able to identify, we should highlight the cultural use of salt. It was blessed in the church at Easter and was then mixed with the rest of the food of the villagers so that this food was also blessed. 'Families ate blessings' we were told by Delfina, one of the inhabitants of Pina de Montalgrao. This same salt was also mixed with the food of the livestock so that they were also blessed and, therefore, protected against the ills and evils that they could suffer.

There was also a formula to prevent animals from being infected by ringworm. They would catch a snake in May, roast it and then crush it to pieces before adding the salt and including it as part of the flock's diet. It is important to highlight the importance of this condiment not only because of its peculiarity and its symbolism related to fertility but especially because of the month in which it was made: essential if the potion was to work.

Another variant of this protection through food is to be found in relation to bread rolls which had been blessed. In Pina, there was a pilgrimage on 22 May, which is Santa Quiteria day, to the hermitage of Santa Bárbara who is well known for her protection against lightning and storms. The bread rolls, which had been kneaded and baked by the dignitaries of the festivities, were blessed on that day. The rolls were shared out amongst those present, and some were even kept for those who were not able to attend. Everyone kept at least one roll at home which they put out on the balconies when there was thunder, evidently to dispel destructive storms. These blessed rolls were also fed to the sheep in small pieces so that they were also blessed and protected from adversity, as Delfina has told us.

In Mora de Rubielos, Teruel, it is also possible to observe the shepherds' use of branches made from rosemary and rue which were blessed on Palm Sunday, as elements of defence against the evils of nature. With these branches, they made crosses, for the festivity of the Crosses of May, on 3 May, which were placed at the entrance of houses, in stables and in fields as well as in the sheep's fleece. Manuel, a shepherd from Riodeva, also talked to us about this custom of placing crosses made of rue in the interior of stables in order to prevent ewes from having miscarriages. These crosses protected them from the storms, foxes and thieves. They were also used to find lost sheep. Once again, we should notice that the element of protection was not the branch itself, but rather the double blessing which it was given. The blessing had to be carried out on a specific date, and the cross had to be modelled on a certain festivity.

A common strategy we have seen amongst Teruel shepherds was to rely on a sacred animal which would protect the flock from lightning. This figure would be embodied by a sheep that was different to the rest: special. It would be a black sheep which had to fulfil certain well-defined characteristics: it had to be the daughter of a white sheep which had to be born black, completely black, without any white markings. If it fulfilled these conditions, indeed exceptional, then it automatically became a blessed sheep and therefore protected the rest of the flock from thunder and lightning. Since it was considered a very special animal, this sheep was obviously not sacrificed for its meat or sold before its death, thus prolonging its protection over the flock. However, its special characteristics did not stop the sheep from being blamed for everything that went wrong, whether it was her fault or not, as Delfina, from Pina de Montalgrao, reminded us. Manuel, from Riodeva, told us that that 
black sheep, which protected the flock against lightning, could not have a single white mark, could not be injured, or bleed, so could not have its tail cut or have its ears tagged.

An intriguing relic of this tradition is maintained in contemporary Castillian, where the term 'black sheep' refers to 'a person who, in a family or small group scenario, is unfavourably different to the rest'.

Other elements of protection against disasters were toads. Vicente, from Pina de Montalgrao, recalls the practice which took place in farms in the area: 'when cattle or sheep died, a live toad was hung from the ceiling and the animals would stop dying'.

A shepherd from Salvacañete, Cuenca recounted a new strategy of protection. In order to prevent foxes from entering the pens, he would make the sign of the cross at the entrance and recite three Our Fathers.

\section{Protection by the Saints}

The patron saint of shepherds in the province of Teruel is, according to the testimonies of numerous sources, Saint Peter, whose festivity, celebrated on 29 June, marks the end of the yearly migratory calendar and starts the next. However, it is a patronage which has more to do with the date on which the Saint is celebrated than with real devotion and protection. Indeed, Saint Peter's day was traditionally celebrated at the end of the contracts between shepherds and their employers. Hence, there was a feast to mark the end of a whole year's work. On that day, owners of the sheep and cattle offered a sumptuous banquet to their employees to thank them for their hard work and sleepless nights, hoping to be able to count on them for the next season. Traditionally, it was also a day when contracts were signed or changed in the case of dissatisfaction between either of the two parties. This feast is still maintained today in some villages such as Fortanete (Teruel), as Lionel, a shepherd from the village, told us.

It is important to realise that Saint Peter is only the patron saint of shepherds from this area. We can, therefore, conclude that there exists a patronage which is more closely linked to the seasonality of each ecosystem than to the universal saint. The shepherds' holiday was set for when there was a break in their activities, and accordingly, a patron saint was chosen whose day fell between the end of spring and the beginning of summer. The patron saint's day would be celebrated during the period between the time the shepherds returned from the valleys to their hometowns and the time when the herds were taken to higher mountain pastures, thereby ensuring the presence of both men and women for the festivity. Nonetheless, this period varied throughout the Mediterranean, depending on the region.
However, shepherds did in fact recognise a common protective saint, with widespread devotion, not necessarily the patron saint. Saint Anthony is the patron saint of animals and therefore not only protected flocks from damage caused by natural disasters but also extended his protection against foxes, the other main enemy of sheep.

The prayer which was recited to the saint has several different versions. For example:

\section{Anthony, holy and divine \\ I beg of you the supreme Good \\ That this lost sheep \\ May appear by your grace. Amen.}

Then a creed would be said to Saint Anthony (referred by Encarnación from Ayodar).

Luis, a shepherd of Puebla de Valverde, gives another version which he learnt from his parents who were also shepherds:

\section{Saint Anthony of Padua \\ Into the fields you went \\ Three things you requested \\ To find what was lost \\ Saint of my devotion \\ That which my heart yearns}

Our sources of information in Pina de Montalgrao, Vicente and his wife Delfina, have told us that on the eve of Saint Anthony's feast, on 17 January, the shepherds also made a small fire at the entrance of the pens in honour of the Saint; this ritual benefitted their sheep: 'a little bit of faith for the animals'. The prayer which was said was the following:

\section{Saint Anthony look after our flocks,}

Both those which are near and those which are not

(in reference to those which had gone amiss). Three Our Fathers were then said.

Manuel's wife, from Riodeva, offers us a later version of this prayer, which could not be recounted because, otherwise, it would have lost its efficiency. It could only be transmitted, as he did with us, in writing:

\section{Antonio, chosen flower, \\ beg to God \\ that all things that get lost, \\ should appear by your grace. Amen.}

\section{Discussion}

Space management is something which is very important in traditional societies. Gluckman (1965) referred to the 
importance of the territorial dimension of relationships in tribal societies. Van Gennep (1960) also developed the concept of frontiers associated to margins. In Spanish villages, it was usual to have boundary crosses, which marked the limits of the village and scared away the evil spirits from the boundaries of their populations. Shepherds crossed these boundaries and constantly moved in what could be considered a liminal space, 'floating between two worlds', an expression used by Van Gennep (1960, p. 18).

This is inferred from the following poem given to us by one of our sources, a shepherd from Linares de Mora, and collected by Bernácer Borona (2010, p. 166):

\section{Oh shepherdess! Oh shepherdess! \\ Do not marry the shepherd! \\ For they will call you shepherdess. \\ Marry the doctor! \\ And they will call you lady}

'The psychology of shepherds, living far from the people of their villages, makes them feel that they are a social category unto themselves' (Mahdi 1999, p. 127).

This opinion is also made clear in the popular phrase picked up by Rodríguez Pascual (2001, p. 22)

\section{Where there are shepherds, there is money.}

According to Angioni (1989, p. 206) 'the more you separate yourself from wife, home and village the nearer you find yourself to uncertainty and danger: a forest becomes demonic, the unknown is confused with that which is negative and useless'.

Lastly, Romantic literature - and to a certain extent, the view held by city dwellers - has tended to portray the life of shepherds and livestock farmers as somewhat idyllic, free from the madding crowds, pollution, traffic and the frenzied hurly-burly of city life. This idea is reflected in the popular saying quoted by Violant $\mathrm{i}$ Simorra (2001, p. 267):

\section{Shepherd's life}

Is an easy life

Singing and whistling

They earn the salary

Elías (2002, p. 111) has a similar version which expresses the same idea:

\section{Shepherds are not men, they are angels from the sky, because when it came to worshiping Baby Jesus, they were the first.}

According to Violant i Simorra (1953, p. 65), the protagonism of shepherds in liturgical acts at Christmas, very common in Catalonian livestock breeding regions, was reminiscent of medieval pastoral dramas which were performed inside or outside church doors and which were especially popular in sixteenth century Provenza. Shepherds would wear their best clothes and take with them one of their most splendid animals:

\section{Shepherds are not men \\ they are uncouth and animals \\ they eat breadcrumbs in a cauldron \\ and celebrate mass in stables (Elías 2002, p. 111).}

This wealth of cultural tradition, which is well documented in other areas such as the Pyrenees (Violant $i$ Simorra 1949, 2001; Pallaruelo 1988) or the Rioja (Elías 2002), amongst others, has been maintained with much difficulty in a large group of shepherds, most of them retired from the Teruel mountainous areas of Gúdar and Javalambre (Vidal-González and Antón 2006):

Life outside the boundaries, with the numerous uncertainties that it entails, demands the shepherd should have rituals and signs which ensure the maintenance of order in the environment which he frequents, as Leach (1976, p. 51) expressed.

Rituals are, following Durkheim (1915, p. 11) 'ways of acting that are generated only within assembled groups and are meant to stimulate and sustain or recreate certain mental states in these groups'. Ritual is, for Rappaport (1999, p. 26) 'the performance of more or less invariant sequences of formal acts and utterances not entirely encoded by the performers'.

Shepherds in the area under study, as in other Mediterranean spaces, would keep these ritual elements as protection and safety in the face of constant liminal tension.

The mentioned use of salt as a vehicle of divine blessing for men and animals can also be found in the herders of the Moroccan Atlas mountains (Mahdi 1999, p. 142).

The presence of extraordinary beings, different and even abominable, as is the case of toads, frogs and snakes, is a classic in anthropological research and has been studied in depth by Douglas (1996) who points out that these beings should be respected, not merely because they were filthy and disgusting but because they were emblematic victims.

The devotion to Saint Anthony, which we have seen to be alive and thriving amongst the transhumant shepherds of Teruel, can also be found in the Pyrenees (Pallaruelo 1988, pp. 187-188) but equally in Corsica (Ravis-Giordani 2001, p. 271) and in mainland Italy (Bucomino 2000, p. 127). The wide dissemination and uniformity of the protection to this Saint is evident. 


\section{Conclusions}

These in-depth interviews with transhumant shepherds have made it possible to identify a rich cultural heritage of traditions which are fully consistent with the deepest popular religiousness. These manifestations are linked with the most atavistic and profound of pastoral traditions. These traditions have basically disappeared due to the extraordinary changes which have taken place in the world and, more broadly, in the rural world. Only the memories of the elderly retain all this tradition, but, unfortunately, all of these will disappear with them.

Another phenomenon which we have observed is the extraordinary geographic magnitude of these manifestations. The world of shepherds seemed to be an isolated one, not well communicated to say the least. However, we have been able to identify rituals which are very similar in spite of the distances between them, not only on the Iberian Peninsula but also in other parts of Europe (France, Sardinia, Corsica, Sicily and mainland Italy, even in the Magreb of North Africa).

Although it is difficult for us to consider these practices as being anything other than local practices or reserved to followers and to those introduced to shepherding as an occupation, we nonetheless found some striking and surprising similarities between these practices and those of other cultures. The works of Violant i Simorra (2001) on pastoral life in the Pallars region of the Catalonian Pyrenees, or of Brisebarre (1996) on shepherds from Cevennes in the south of France, and of Doazan (1995) - many of them unpublished - on transhumance on the Isle of Corsica reveal a broad-based, ingrained, pastoralist culture that encompasses many striking and surprising common elements and can only be the result, in our opinion, of the connections and movements that traditionally existed among the pastoralist communities. Many of these magical, traditional, ingrained practices seem to take us back to prehistoric times - to the start of the Neolithic period when man first domesticated animals, having spent many years following them in their natural seasonal migrations for hunting. The survival of these traditions is a treasure that tells us of a common origin, of an open, shared space, whose limits we are incapable of defining.

There is, therefore, an important common substratum of heritage and tradition, a testimony of movement and interaction which we can only imagine nowadays and which takes us necessarily back to days gone by.

The deep connection between the different cultural practices of pastoralism in the Mediterranean should encourage us to make greater efforts in comparative studies on these cultures in order to highlight the close links that have been established since ancient times.

The close relationship which shepherds maintained with their environment with its unexplored nature, beyond the limits of civilisation, of that which is known, made a lasting mark on these people. The challenges which they have had to overcome by themselves, isolated, faced by the dangers of severe weather and wild animals, and a terrain which was not always favourable, left their mark not only on their character but also on the culture of folk who had to manage their flocks, full of bravery, in a hostile environment, developing very peculiar strategies of survival and protection.

Shepherds' extreme vulnerability to bad weather conditions, diseases and other adversities such as theft, wars or looting led to the creation of a whole protection system, based on ancestral practices and rituals, to safeguard them from the hazards they were exposed to in their jobs. Nonetheless, these seemingly magical practices also used the resources available to traditional societies, such as yearly festivities, exotic plants and animals or unique moments, to ensure protection. All of which further underlines how shepherds were exposed in their occupation, working alone in the solitude of the mountains and open spaces, far from the protection to be found in the shelter of towns and villages.

Lastly, it is important to realise that a shepherd is not, and was not, an isolated being but rather a vehicle of communication, of interaction and also a bearer of knowledge and culture. The deep legacy of a shepherd, with its complex rituals, formulae and devotions, hid a very different religiousness, unique and yet profoundly orthodox but, which basically offered a transcendental meaning, linked to this close connection with nature. This has created growing interest from social anthropological researchers.

\section{Consent}

Informed consent was obtained from the respondents to use the information contained in this report.

\section{Endnotes}

${ }^{\text {a }}$ Person paid for the municipality to watch over the cultivated fields in the municipal territory.

${ }^{\mathrm{b}}$ Traditional dances from the shepherd's home region.

Competing interests

The author declares he has no competing interests.

\section{Author's information}

PVG is the director of the Anthropology Research Institute at the Catholic University of Valencia, Spain and Professor of Social and Cultural Anthropology at the same university. He has conducted research in Spain, Corsica and Morocco where he has been the main researcher of different R\&D projects on Transhumance in the Medium Atlas. He was the main researcher for a three year European Project on Landscape Anthropology in European Protected Areas.

Acknowledgements

This research is part of an R\&D Project granted by the Valencian Region Government, Spain.

Received: 17 April 2013 Accepted: 30 July 2013

Published: 1 November 2013 


\section{References}

Agulló, JE. 2009. Itinerant spaces: Transhumant pastoralism and social liminality, (Espacios itinerantes: trashumancia pastoril y liminaridad social). Ager 8: 75-93.

Angioni, G. 1989. The wandering sheep: Shepherds anthropology in Sardinia (I pascoli erranti: Antropologia del pastore in Sardegna). Napoli: Liguori.

Bernácer Borona, C. 2010. Transhumant shepherds of the Gúdar-Javalambre region: development of a trascendental sense of community (Pastores trashumantes de Gúdar-Javalambre: la evolución de su sentido comunitario y trascendente). In Transhumant pastoralism in the Mediterranean, ed. P Vidal-González and JL Castán Esteban, 165-177. Zaragoza: Ceddar.

Brisebarre, AM. 1996. Cévennes shepherds: History and ethnology of the shepherd's works and of transhumance in Cévennes (Bergers des Cévennes: Histoire et ethnographie du monde pastoral et de la transhumance en Cévennes). Montpellier: Espace-Sud/Presses des Baronnies Honology.

Bucomino, V. 2000. The transhumant pastoralism culture in social anthropology (La cultura della trasumanza in un percorso socio-antropologico). In Madonna, Santi e Pastori, ed. Giooelli, 117-129. Campobasso: Palladino Ed.

Castán, JL. 1999. Family strategies and nomadic pastoralism in the Teruel mountains (s. XVI-XVII) (Estrategias familiares en las sierras trashumantes turolenses (s. XVI-XVII)). Studium: Journal of Humanities 6: 25-39.

Doazan, L. 1995. Summer Piazzile visited: Notebook no 46 (Piazzile d'èté visité: Cahier no 46). Cahier d'Anthropologie 2: 46-84.

Douglas, M. 1996. Thought styles: Critical essays on good taste. Thousand Oaks: Sage.

Durkheim, DE. 1915. The elementary forms of the religious life. London: Allen \& Unwin.

Elías, LV. 2002. Transhumant herders of the Rioja (Trashumantes riojanos). La Rioja: Government of La Rioja.

Gluckman, M. 1965. Politics, law and ritual in tribal society. Oxford: Basil Blackwell.

Klein, J. 1920. The Mesta: A study in Spanish economic history, 1273-1836. Cambridge: Harvard University Press.

Leach, E. 1976. Culture and communication: The logic by which symbols are connected. Cambridge: Cambridge University Press.

Mahdi, M. 1999. Shepherds of the Atlas: Pastoral production, law and rituals (Pasteur de l'Atlas. Production pastorale, droit et rituel). Casablanca: Fondation Konrad Adenauer.

Pallaruelo, S. 1988. Shepherds of the Pyrenees. (Pastores del Pirineo). Madrid: MdCultura.

Rappaport, RA. 1999. Ritual and religion in the making of humanity. Cambridge: Cambridge University Press.

Ravis-Giordani, G. 2001. Corsican shepherds: Niolu rural communities. (Bergers Corses: Les communautés rurales du Niolu). Ajaccio: Albiana/PNRC. (reed).

Rodríguez Pascual, M. 2001. Transhumance: Culture, tracks and travel (La trashumancia: Cultura, cañadas y viajes). León: Ed. Edilesa.

Turner, V. 1974. Dramas, fields and metaphors. Ithaca: Cornell University Press.

Van Gennep, A. 1960. The rites of passage. London: Routledge.

Vidal-González, P. 2006. Bajar al Reino: Anthropology of a return journey (Bajar al Reino: Antropología de un camino de ida y vuelta). In Transhumance of shepherds from the Teruel region to the Espadán mountains (Castellón) (Trashumancia de los pastores turolenses a la Sierra de Espadán (Castellón)), ed. P Vidal-González and FJ Antón Burgos, 27-43. Madrid: Publ. Complutense Madrid University and Catholic University of Valencia Presses.

Vidal-González, P, and J Antón. 2006. Transhumance of shepherds from the Teruel region to the Espadán mountains (Castellón) (Trashumancia de los pastores turolenses a la Sierra de Espadán (Castellón)). Madrid: Publ. Complutense Madrid University and Catholic University of Valencia Presses.

Violant i Simorra, R. 1949. Pastoral life. In The Spanish Pyrenees: Life, uses, customs, beliefs and traditions of a milennary culture which is disappearing. (IX. La vida pastoral, en El Pirineo Español. Vida, usos, costumbres, creencias y tradiciones de una cultura milenaria que desaparece), 379-435. Barcelona: Alta Fulla (1986).

Violant i Simorra, R. 1953. Shepherds and music (Els pastors i la música), vol. 10. Barcelona: Library of Folklore Barcino.

Violant i Simorra, R. 2001. Shepherd's life in Pallars. In , ed. I Ros i Fontana Garsineu: Tremp: Ramón Violant i Simorra Library.

doi:10.1186/2041-7136-3-24

Cite this article as: Vidal-González: Sacred rituals and popular religiousness amongst transhumant shepherds of Teruel region, Spain Pastoralism: Research, Policy and Practice 2013 3:24.

\section{Submit your manuscript to a SpringerOpen ${ }^{\circ}$ journal and benefit from:}

- Convenient online submission

- Rigorous peer review

- Immediate publication on acceptance

- Open access: articles freely available online

- High visibility within the field

- Retaining the copyright to your article

Submit your next manuscript at $\gg$ springeropen.com 